\title{
Science-Trained Journalists at University Public Relations Divisions: Trying to Find them!
}

\author{
J. Sean McCleneghan* \\ New Mexico State University, Mexico
}

\begin{abstract}
This content analysis study explores if science-trained journalists are specifically writing science stories for general media consumption in public relations divisions at U. S. comprehensive research universities. In a national economy today that rivals the Great Depression, are research universities able to hire more science-trained reporters to tell their stories about cutting edge science and technology? With the severe economic cutback of science-trained reporters at mainstream metropolitan newspapers and cable television stations from 2008-2012, who is left in the Fourth Estate to independently critique the science research produced at our comprehensive research institutions? Are those "laid off" science-trained reporters finding employment at comprehensive research universities? Are science-trained reporters writing those important science stories or do university general assignment staff reporters craft them for local, regional, national and international media consumption? This content analysis study of the 49 U.S. universities belonging to the Futurity.org science consortium suggests few science-trained reporters from 2008-2012 have been hired at the research universities. In fact, more general assignment writers with journalism degrees continue to craft most of the science stories for understaffed PR divisions of the major research universities belonging to Futurity.org science consortium.
\end{abstract}

Keywords: Science-trained journalists; Public relations; Third-party endorsement; Blogs; Mainstream press; Content analysis

\section{Introduction}

On the campus of the University of California at Davis, Dr. Paul S. Moller, a professor of mechanical and aeronautical engineering, is minutes away from flying his experimental XM-2 VTOL (vertical takeoff and landing) Sky Car. More than 200 members of the mediaincluding the international press-attend to see what will happen. Dr. Moller's craft lifts a few feet above the ground and the mainstream press calls his flight successful and the XM-2 VTOL experimental Sky Car a "flying saucer" [1]. So much for science reporting in the mid-60s (Figures 1 and 2). 1966, Paul S. Moller flying his XM-2 Sky Car at the University of California at Davis Airport. Photo credit: unidentified.

But science reporting dramatically changes in the next 17 years [2]. By 1990 newspaper science reporting is serious business and scores of mainstream daily newspapers publish special stand-alone sciencetechnology sections edited and written by science-trained journalists [3]. McCleneghan [4] surveyed N=83 science reporters writing for 103. Metro newspapers with circulations in excess of 100,000. Using factor analysis statistics on 17 attitudinal instatements he developed, a PAF three-factor loading solution was named: I Beat Pressure, II Creative Talent, and III Reporter Responsibility. None of those 83 science reporters today-who participated 18 years ago in his national science

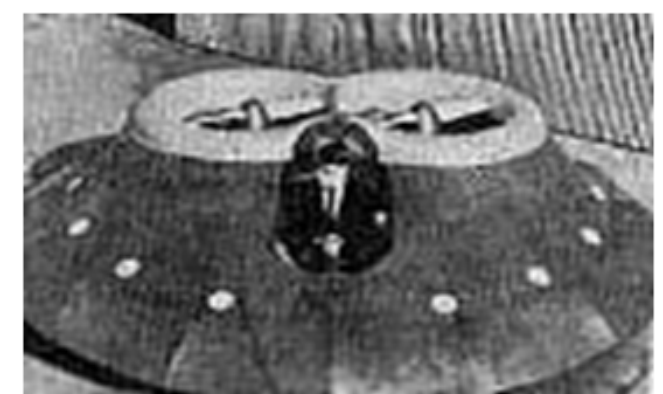

Figure 1: 1966, San Francisco Examiner photo, Paul S. Moller. reporting attitudinal survey-are still employed by their respective newspaper. What happened?

\section{Media landscape perspective}

Mutter [5] reported newspaper advertising dropped 6.3 percent at the end of 2010. Today's challenging U.S. economy has put additional pressure on the media to reduce newsroom costs [6].

Palmer [7] wrote media employment alarms went off and became impossible to ignore after the entire CNN science team lost jobs in 2008. She blogged: For mainstream outlets like $\mathrm{CNN}$ or the Boston Globe to cut science may seem appealing, but in an unforgiving economic climate which has already triggered the collapse of major newspapers like the Seattle Post-Intelligencer, such cuts are logical, because science reporting isn't a big moneymaker [7].

Timmer [8] blogged there was a disproportionate "toll cut" on

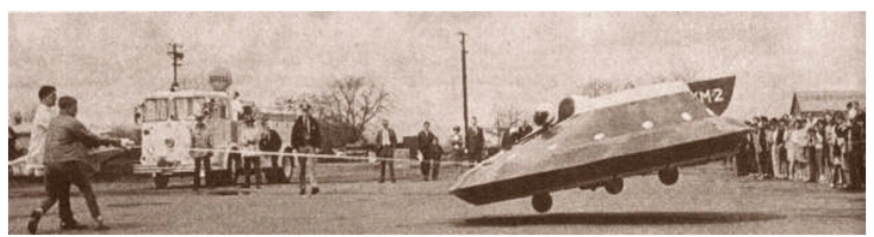

Figure 2: 1966, Paul S. Moller flying his XM-2 Sky Car at the University of California at Davis Airport. Photo credit: unidentified.

*Corresponding author: J. Sean McCleneghan, Professor, New Mexico State University, Mexico, E-mail: smcclene@nmsu.edu

Received October 08, 2012; Accepted December 17, 2012; Published December 24, 2012

Citation: McCleneghan JS (2013) Science-Trained Journalists at University Public Relations Divisions: Trying to Find them!. J Mass Communicat Journalism 3:141. doi:10.4172/2165-7912.1000141

Copyright: () 2013 McCleneghan JS. This is an open-access article distributed under the terms of the Creative Commons Attribution License, which permits unrestricted use, distribution, and reproduction in any medium, provided the original author and source are credited. 
science journalism. "Many news establishments—-who have eliminated their science staff-have handed it off to journalists with no science experience," he wrote.

President of the International Science Writers Association (ISWA), estimated some 5,900 full-time newsroom jobs-about 11 percent of the U.S. news work force-were lost in 2008. "Almost every major daily paper-with the notable exception of The New York Times-has dropped its special science section. Even profitable science magazines are now defunct, or have morphed into Web-based digital versions," Cornell said.

Obviously science journalism faces a crisis and a challenge. How does it find an audience for serious, thoughtful reportage about difficult technical subjects and complex issues in an era of superficial, sensational, celebrity-based journalism, where economic and cultural forces are killing traditional media, and long-form reportage has been replaced by 140 -character-long banalities [9]?

Timmer [8] also reported the net result is that public relations officers of major universities-whose job is to help increase the public's recognition of the research that goes on there-felt they were speaking to an empty room. "Their solution has arrived in the form of Futurity. org, a site that aggregates a selection of the research releases they used to feed to the press," Timmer said. According to him, Futurity.org serves as an online science "newswire." Because of the severe decline in mainstream press science coverage, 35 of the country's top research universities banded together to launch their Futurity.org newswire for publicizing their best research, reported [10]. Brainard is the editor of the Columbia Journalism Review's "Observatory"-an online critique column of science and environmental reporting.

Brainard [10] reported the 35-research university consortium created the Futurity.org website to showcase edited press releases and stories written by member schools. Founded by the senior communications officers at Stanford, Duke, and the University of Rochester, the project has grown and evolved with Futurity.org now seeking syndication deals with Google News and Yahoo News.

Because of the widespread cuts to science staffs and sections in print and television, a number of organizations have launched similar endeavours, from the National Science Foundation's “Science 360" web site to the independent "Science Daily" web site.

However, Brainard [10] has questioned the "effectiveness" of all science online sites. He asked, "What are the implications of "by passing' traditional news outlets?"

"These online sites are completely absent of any scepticism or investigative side," reported Charlie Petit, a former science reporter at U.S. News \& World Report and the San Francisco Chronicle [11]. "However, any information is better than no information," Petit said, "and the quality of university research news releases is quite high and rather reliable."

Petit should know. He produces a daily science weblog published by MIT and earned the 2011 Robert C. Cowen Award for Sustained Achievement in Science Journalism from the American Geophysical Union [12].

Brumfiel [13] reported today's science bloggers rely heavily on the public relations departments of scientific organizations. As newspapers employ fewer people with science-writing backgrounds, press offices are employing more of them. "Whether directly or indirectly, scientists and the institutions at which they work are having more influence than ever over what the public reads about their work [13]".

\section{University PR division context}

Pressure continues on university PR divisions today to earn positive and credible news attention within the Fourth Estate. The publishing of a newsworthy story that earns a third-party endorsement is, of course, only one of many reasons why PR offices exist on college campuses [14]. The third party endorsement is the verification of a public relations story's "newsworthiness" that mainstream media provide when publishing or airing the story [15].

The research investment stories earning a third party endorsement in mainstream print or a television newscast bring prestige and satisfaction to a university. However, the competition for mainstream coverage is fierce. Every academic medical center in the U.S. fights to secure column inches, broadcast time units and positive online media buzz.

Consider what the University of Pittsburgh's Medical College News Bureau (UPMC) did in 2001. It's one of the largest and most productive news operations specializing in the promotion of academic medicine. In 2001, the UPMC employed 11 professional and four support staff members who produced almost 8,000 mainstream media placements. This number included national and international newspaper and wire service articles, network and cable television and radio interviews, and daily local coverage in all media [16].

But with science reporting cutbacks in the mainstream media from 2008-2012, there are now fewer chances of getting a good science story published as a credible third party endorsement for a powerful research institution. A university's public relations division suffers a severe credibility gap if its science stories can't get published when newspaper science reporting column space and television time units are eliminated in large chunks. Such cuts provide fewer opportunities for a reputable third party endorsement in the mainstream media.

Questions then arise about the PR division's importance and worth as a stand-alone campus office by top-down senior administrators. Brilliant campus scientists, who need a positive Fourth Estate buzz for their continued research funding, then complain to their respective administrators. Powerful alumni, who contribute large monetary gifts, then ask, "Why isn't State U.S. getting good press?"

Public relations administrators understand the proverbial question, "What have you done for me lately?" They understand the negative consequences within today's hostile $24 / 7$ online carnivorous media environment [14]. And, university PR divisions are also dealing with their own staff downsizing and budgetary problems in today's horrible national economy [17].

\section{Purpose of the study}

The purpose of this study is to document if science-trained reporters are finding employment opportunities with public relations divisions at powerful U.S. research universities. It covers the 2008-2012 time frame periods when mainstream science reporting cutbacks in print and television began.

The investigator initiated the study with a pre-test e-mailed survey in July 2011. Five discrete YES / NO variable questions and one openended question were sent to 15 selected western public universities. It soon was evident the online survey was not going to generate an acceptable response rate. Ninety days later only 20 percent of the pre- 
test questions were answered following multiple attempts to university PR division administrators for their responses.

\section{The questions asked were:}

1. Is covering science on your campus given more priority than other university news? (e. g., compared to art exhibits, concerts, speakers, faculty and students earning awards, etc.).

\section{YES NO}

2. Have you hired a science-trained journalist to specifically write campus science stories from 2008-2011?

\section{YES NO}

3. These are difficult economic times in America. State budget reductions over the past three years are challenging public universities. At present, do you have a WRITING VACANCY on your staff?

\section{YES NO}

4. If that WRITING VACANCY does exist, can you afford to hire a science-trained reporter or will you hire a general assignment reporter with professional newspaper or television experience?

YES NO

5. Do your staff writers check stories with their research sources before they are released to the media?

YES NO

6. Please make any final comments (if you care to) about hiring the right reporting staff to tell your (name of school) story under the present economic conditions you face.

\section{The midpoint methodology correction}

The investigator decided to make a midpoint methodology correction in the pre-test e-mailed survey because the initial response rate was unacceptable $(3 / 15=20$ percent). The investigator determined that Futurity.org should be the starting point for the study. Could science-trained reporters be uncovered using a content analysis methodology at those 49 U.S. universities in Table 1 belonging to the science consortium Newswire?

The Futurity.org science consortium institutions-who each pay a $\$ 2,000$ membership fee to belong-are producing sizable amounts of quantifiable stories for public consumption in medicine, science, technology, the environment, and the social sciences.

\begin{tabular}{|l|l|l|}
\hline $\begin{array}{l}\text { N=667 total PR staffers identified at 49 uturity.org sci- } \\
\text { ence consortium universities. The PR staff average } \\
\text { was }\end{array}$ & 13.6 & \\
\hline $\begin{array}{l}\text { Science-trained journalist staffers identified } \\
\text { Science-trained journalist staffers hired from 2008-2012. }\end{array}$ & 83 & $(12.4)$ \\
\hline Journalism degree staffers identified. & 272 & 18 \\
\hline Journalism degree staffers hired from 2008-2012 & 31 & $\begin{array}{l}\text { "Other" degrees } \\
\text { earned by staffers }\end{array}$ \\
\hline $\begin{array}{l}\text { In the non-sciences } \\
\text { "Other" degree staffers hired from 2008-2012 in the } \\
\text { non-sciences }\end{array}$ & 143 & $(25.9)$ \\
\hline $\begin{array}{l}\text { 139 staffers could not be fully identified by their } \\
\text { earned degree(s) their prior professional media } \\
\text { experience or their respective campus beat. }\end{array}$ & 139 & $(20.8)$ \\
\hline & $\mathrm{N}=667$ & $(99.9)$ \\
\hline
\end{tabular}

Table 1: The PR Staff Results of 49 Futurity.org Universities in the Content Analysis Study.
The investigator thought the science consortium institutions might be employing more science-trained journalists to cover their scientific campus beats in the physical sciences, natural sciences, and their respective colleges of medicine and colleges of engineering. How many newly hired, science-trained journalists from 2008-2012 might be uncovered?

\section{Content analysis procedure}

Krippendorff [18] wrote, "The pursuit of content analysis is fundamentally empirical in orientation, exploratory, concerned with real phenomena, and predictive in intent." Content analysis is also a labour-intensive research method. Its procedures must be explained carefully and the items selected must be carefully defined from observable facts.

In this study, a critical codification decision had to be made by the investigator dealing with nominal data. The codification condition-where a science-trained journalist position was thought by the investigator to exist-had to be arbitrarily assigned based on observable facts.

Using the 2011 Constitution of the National Association of Science Reporters (p. 1) as a guideline, the investigator developed four arbitrary classifications based on observable facts. The observable facts were: a PR staff writer's earned degree(s), prior professional media experience, and his/her present campus beat assignment. The four arbitrary assigned classifications were:

1. If the PR staff writer had earned an undergraduate degree in the sciences and then went on to earn a master's degree in journalism, the codification of "science-trained journalist" was assigned.

2. If a PR staff writer had earned both an undergraduate and graduate degree in the sciences and practiced in the media two or more years, the codification of "science-trained journalist" was assigned.

3. If a PR staff writer had earned a M.D. or Ph.D. degree and covered a campus science beat, the codification "science-trained journalist" was assigned.

4. If a PR staff writer had earned an undergraduate degree in the sciences and practiced in the media two or more years, the codification of "science-trained journalist" was assigned.

If one of the four arbitrary classifications were met, the respective university's PR division was judged by the investigator to have a science-trained journalist aboard.

The exact procedures in this content analysis investigation were done in this order: (1) Staffers were quantified by total head count for each of the 49 PR divisions belonging to Futurity.org. Staffers were then (2) divided into two groups by the type of college degree earned (e.g., a journalism degree or "other" academic discipline). Then (3) the specific year each staffer (e.g., specifically from 2008-2012) joined the PR office was determined. Then (4) the professional media experience of the staffer was determined. Finally, (5) the staff writer's campus beat was determined.

In this content analysis study, the PR division's individual media department might be called or named:

Media and Public Relations Office

Media Relations Office

Media Relations \& News Services 
News Bureau Office

News \& Communication Office

News Desk Office

News and Information Office

News Media Center

News Service Office

Press Relations Office

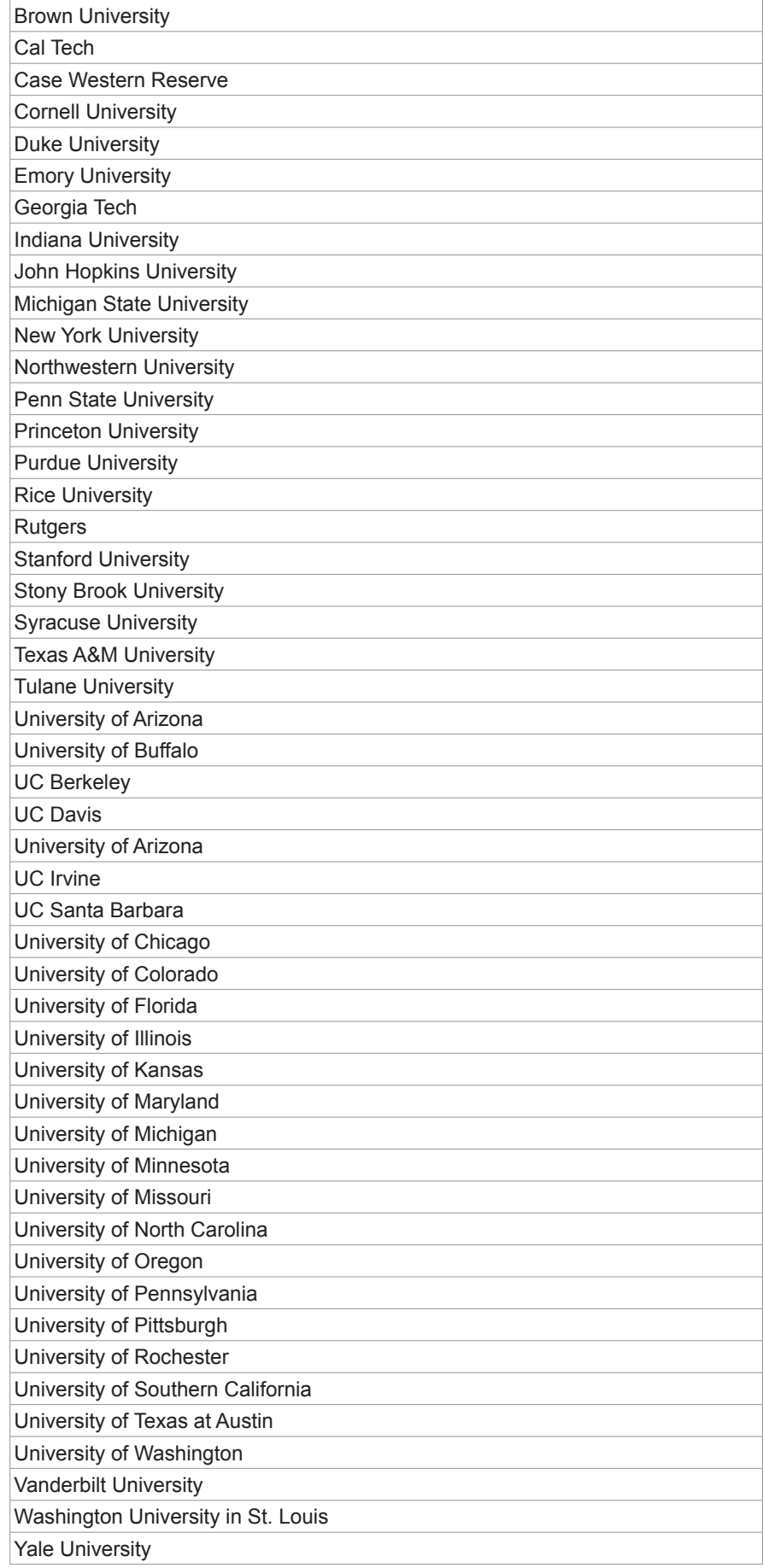

List 1: The 49 Futurity.org U.S. Research Universities.
Public Affairs Office

Public Information Office

Publicity \& Media Relations Office

Public Relations Office

University Communications Office

University News Office

University Relations Office

Four individual examples below are illustrated in how the PR divisions-belonging to the Futurity.org university science consortium in List 1 were content analysed by the investigator to identify sciencetrained journalists:

University of California at Davis (UCD): Office name: University Communications. Ten (10) staffers produce content. Four staff members have a B.A., B.S. or master's degrees in journalism; six staff members have earned "other" degrees at the baccalaureate level. Two staff writers were hired in 2008 and 2011. The 2008 staff writer hire earned a B.S. degree in zoology and Ph.D. in immunology. The investigator codified that 2008 staff writer hire as a science-trained writer. That writer's campus beat also included the physical and biological sciences, computer and quantitative sciences, and the College of Engineering at UCD. The 2011 staff writer hire earned a B.A. degree in journalism and covers business, education, humanities, social sciences, and law at UCD.

University of Colorado at Boulder: Office name: Media Relations \& News Services. Eleven (11) staffers produce content. Five staff members have earned B.A., B.S. or master's journalism degrees. Two staff members have earned "other" degrees. The science-trained reporter earned a B.A. degree in environmental biology and covers the natural and physical sciences. Four of the 11 staffers could not be fully identified. No new science reporter hires could be determined from 2008-2012.

University of Florida: Office name: News Desk. Ten (10) staffers produce content. Nine staff members have a B.A., B.S. or master's degree in journalism. One staff member could not be fully identified. No new science-trained reporter hires could be determined from 20082012.

University of Illinois: Office name: News Bureau. Twelve (12) staffers produce content. Nine staff members have earned B.A., B.S. or master's degrees in journalism. Three staff members have earned "other" degrees. Two science-trained reporters earned B.S. degrees in biology and one master's degree in life sciences communication. One science-trained reporter covers agriculture, applied health sciences and life sciences. The other science-trained reporter covers engineering and the physical sciences. There were three staff hires from 2008-2012. One science-trained journalist was hired in 2011. Two staffers also hired in 2011 have earned journalism degrees.

\section{The real hunt for science-trained reporters}

Not all of the 49 U.S. universities listed in List 1 are a profile brief of individual staffers on their PR division's respective web pages. Almost 68 percent of the 49 universities in this study did not give any relevant information about their staffers who serve their respective internal and external publics. The majority of Contact Us links gave only e-mail addresses and job titles for the respective staffers and nothing more. This became a major hurdle in this content analysis study of identifying 
the number of science-trained journalists on PR division staffs. Thus, the real hunt for science-trained reporters began.

The investigator had to search the Internet for each respective PR staffer's name to see if the pertinent information sought could be uncovered. When university PR divisions listed 20 or more staffers, the hunt for science-trained journalists became even more laborious. Still, some cursory information could be found on LinkedIn. However, any incomplete information on any individual PR staffer resulted in the investigator codifying the staff person as unidentified. The investigator could not fully identify 139 PR staffers employed at the 49 Futurity.org U.S. universities under investigation.

\section{Results}

The final sample size uncovered by the investigator was $\mathrm{N}=667$ PR staffers working at the 49 Futurity.org science consortium U.S. universities in this study. The $\mathrm{N}=667$ sample also included those PR staffers working for individual schools/colleges of medicine, health sciences and engineering within the respective university's public relations division. The $\mathrm{N}=667$ staffers produce content for both internal and external publics. However, 139 PR staffers (20.8) out of the $\mathrm{N}=667$ total head count could not be fully identified by the investigator. The results are presented in Table 1.

\section{Limitation of Content Analysis Study}

Again, the investigator could not fully identify 139 PR staffers employed at the 49 Futurity.org U.S. universities under investigation. It's the major limitation of this content analysis study and here is why: Inter-coder reliability is the heart of content analysis. It refers to the extent or degree of agreement among independent coders. If the coding is not reliable, the analysis cannot be trusted.

Stempel [19] said the appropriate thing to report for an inter-coder reliability statistic "is simply the percentage of agreement between coders." "It's an accepted way of reporting reliability," he reported, "but what percentage is acceptable is entirely a matter of judgment."

It's one thing to report an inter-coder reliability statistic to address what might be acceptable in a content analysis study, but it's quite another to deal with missing data totaling almost 21 percent in this science-trained reporter identification research.

Those 139 unidentified staffers represent missing data. Therefore, one can only report that maybe 83 (Table $1,12.4 \%$ ) science-trained journalists from the $\mathrm{N}=667$ sample size were actually identified by the procedures and arbitrary classification categories developed and used by the investigator.

Therefore, an inter-coder reliability statistic was not computed for this science-trained journalist identification content analysis study. It was the investigator's conscious decision not to compute one because 139 PR staffers could not be fully identified by the selected arbitrary procedures and parameters.

\section{Discussion}

Cornell [9] said the main sources of science news are rapidly becoming those very organizations that do the research. The public relations divisions of many research institutions now communicate directly with the public without going through an outside reporter. This makes for easy, effective transmittal of information.

"It also eliminates an independent press because there is almost no one to evaluate this information, critique the research, or check the credentials and financial interests of the researchers," Cornell [9] said.

The U. S. National Association of Science Writers (NASW) still has almost 3,000 members, but less than 70 of them are full-time staff reporters or editors for news organizations. The rest of them are freelancers, educators, or public relations practitioners [9].

The Futurity.org university science consortium is a prime example of how PR divisions are communicating directly with the public without earning an independent mainstream media third party endorsement.

But let's be clear. It's not the fault of any university's PR division that independent science-trained reporters have been "cut" or that science newspaper sections and TV news segments have been "gutted." It's not the fault of university PR divisions that steep budget cuts in the media no longer allow mainstream science reporting experts to critique university scientific research, or check the credentials and financial interests of the university's scientists.

So, what is acceptable? What should happen in today's bleak economy and gloomy mass media landscape?

University PR divisions should still try and hire science-trained journalists to cover their specific campus beat stories in medicine and science. And, those science-trained journalists must background stories with their research scientist sources before the stories are disseminated. Most already do because science news often is so complex today that even newspaper and TV reporters must step outside standard journalistic practice to get the facts right.

"I have never admitted this before," Tim Friend told a Freedom Forum-sponsored conference in 1997, "but if I want to sleep the night before a complex science story goes out, I go over it word by word with the source to make sure the facts are all straight" [20].

Friend is a former veteran science reporter for USA TODAY. He worked with USA TODAY for 17 years. Friend said science stories are especially susceptible to misinterpretation. "We have the scientists who are the experts, the reporters who are trying to interpret, and then the gatekeepers-the editors-who know less than the science writer and a little bit more than the general public," Friend said [20].

The universities with powerful steam engine research missions were perceptive in developing a science consortium such as Futurity. org. Each PR science story that is posted also has the original refereed scientific journal article embedded in it.

It's only a mouse click away for providing the comparative transparency between the PR story and the original scientific work. This provides a wonderful comparative match-up for the public or any independent journalist wanting to view everything thanks to today's online technology.

Four science-trained journalists and four "other" PR staff writers were credited with earning Top 10 science stories in 2011 for Futurity. org. Chris Privett from Duke University wrote two of the Top 10 science stories.

Duke University (e.g., Privett's two stories) and the University of Buffalo each had two Top 10 stories. The other research institutions named for contributing Top 10, 2011 science stories were: Emory University, Penn State, Michigan State, University of Colorado, and the University of Pittsburgh.

The University of Nottingham (UK) was also recognized for producing a Top 10 science story, but those international institutions 
belonging to the Futurity.org science consortium were not part of this content analysis study. Only U.S. universities were examined.

\section{Conclusion}

What about blogs? Where do they fit? Can't blogs carry the load of independent science-trained reporters critiquing university research stories?

The answer at present is "no."

"Today's blogs aren't a replacement for traditional journalism; they're a complement to it," [7] reported. "While science blogs may eventually fill the void left by the regrettable decline of traditional science journalism, to do so credibly, they're going to have to evolve into something better adapted to the task," Palmer said.

"Blogs, as a genre, seem to have a very short shelf life. Science blogs written by scientists, like science web sites, appeal to very small, specialized audiences, differentiated by disciplines-biology, astronomy, archaeology—rather than general interest science" [9].

Cornell [9] also reported the blog search engine "Technorati" estimates only 7.4 million of the 133 million blogs it monitors had been updated in the past 120 days. "In other words, 75 percent of blogs are simply abandoned by their owners, usually due to lack of interest or response," he said.

Mainstream media today are no longer as powerful and prosperous to do the type of independent in-depth science reporting once done regularly more than 30 years ago. All one has to do is look at the low ebb of mainstream media investigative reporting.

Only a few national media vehicles attempt it anymore. Most won't. Libel suits are time-consuming and expensive. The New York Times, Washington Post and 60 Minutes (CBS) are but a few of the major media leaders left today who can do in-depth and investigative journalism because of their size and profitability. Investigative reporting takes time, commitment and resources.

So how can mainstream media be expected to do an independent review of a science story in today's economic and mass media climate? It's going to be more difficult. In today's terrible economic card shuffle, a university's public relations division may well be the last outpost for evaluating a science story for credibility and truthfulness.

It now falls on the shoulders of those comprehensive research universities to hire science-trained reporters to cover their colleges of medicine, colleges of engineering, and the physical \& natural sciences. Research universities should be diligent in supporting a specific mission of an independent review documenting scientific discovery for credibility and truthfulness.

Those same universities should also continue hiring general assignment reporters-with earned journalism degrees-who are essential in reporting social science research and other non-science campus beats. Those reporters are versatile in their writing and reporting. They bring to the table prior professional media experience and thoroughly understand context and perspective. Many of those journalism-degreed professionals are already today's "science reporters" for many university PR division staffs in our downturn national economy.

The bottom line is that both science-trained journalists and nonscience trained journalists will do the right thing for each university's
PR division because after all, credibility and truthfulness are the Golden Rule attributes for public relations practice.

\section{References}

1. San Francisco Examiner (1966) A Two-Seater Saucer for '70's? 1C

2. McCleneghan JS (1983) 'Science Reporting Blight' is Challenge to J-Education. Journalism \& Mass Communication Educator 38: 16-17.

3. Miller S (1990) Covering Science and Environmental Issues Every Day Scripps-Howard Editors Newsletter 2: 1

4. McCleneghan JS (1994) The 1993 Newspaper Science Reporter: Contributing Creative, and Responsible. Social Science Journal 31: 467-477.

5. Mutter AD (2011) Why newspaper ad sales are not recovering. Reflections of a Newsosaur (blog).

6. Associated Press (2011) Weak economy leads Charlotte paper to cut 26 jobs.

7. Palmer J (2009) Is the internet to blame for the decline of science journalism? And can blogs fill the void?

8. Timmer J (2009) PR or science journalism? It's getting harder to tell.

9. Cornell J (2009) The Rise and Fall-and Possible Rise Again-of Science Journalism. A paper presented at the First International School of Scientific Journalism and Communication. Erice, Sicily, Italy.

10. Brainard C (2009) Is Futurity the Future? Citing a Lack of Science Coverage, Universities Launch Their Own Newswire. Columbia Journal Review's The Observatory, a lens on the science press.

11. Schwitzer G (2009) Universities Create Their Own Science-Medicine News Wire Service. (blog). Schwitzer reported on his blog what the San Jose Mercury News initially reported.

12. AGU News Release No. 11-24 (2011). Charles Petit and Steve Connor Win AGU Journalism Awards. American Geophysical Union News Release.

13. Brumfiel G (2009) Science journalism: Supplanting the old media?

14. McCleneghan JS (2008) PR Educators' Opinions About the Third-Party Endorsement. Public Relations Quarterly 52: 34.

15. Guth D, Marsh C (2006) Public Relations: A Values-Driven Approach (3rdedn) Pearson Education, Boston.

16. Pitt C (2001) UPMC News Bureau Packages, Pitches Medical Stories.

17. McCleneghan JS (2006) University PR Managers: 'Marketing' the Product with Less Resources. Public Relations Quarterly 51: 40-45.

18. Krippendorff K (1980) Content Analysis: An Introduction to Its Methodology. (Vol 5). Sage Publications, Beverly Hills, London.

19. Stempel GH (1981) Content Analysis in Research Methods in Mass Communication (Eds: Stempel, Westley BH), Prentice-Hall, Englewood Cliffs, New Jersey.

20. Gordon T (1997) Science Writer Checks Stories with Sources. The Freedom Forum \& Newseum News 4: 8 . 